\title{
Putting science on the map
}

Leonard Krishtalka

National Geographic Research. Editor Harm J. de Blij. National Geographic Society. 4lyr. US \$40; Canada \$61.85; elsewhere \$45 (surface), \$60 (air).

GEOGRAPHY is the science of place. Its vision is grand, its view panoramic. It sweeps the surface of the Earth, charting the physical, organic and cultural terrains, their areal differentiation, and their ecologic dynamics with man. Its foremost tool is the map.

Ever since its founding in January 1888 , the National Geographic Society has remained faithful to the romance of geography. From the lead article in the inaugural National Geographic Magazine in October 1888 ("Geographic Methods in Geologic Investigation") to the last one in the July 1986 issue ("Model Airplanes: and then to Fly"), its sense of geography has remained classical: the physical contours and features of the continents and oceans; life on Earth, past and present; human cultures, traits and economies; the evolution of man; the geography of space beyond Earth; and, of course, smashing colour photography and so many fine maps.

In keeping with its charter ("for the increase and diffusion of geographic knowledge"), the society began funding geographic exploration and research just after its inception. As of this year, it has supported over 3,000 such projects, notably Peary's final assault on the North Pole, Byrd's expeditions to the South Pole, the archaeological unearthings of Machu Pichu (Peru) and Chaco Canyon (USA), two generations of Leakeys in the badlands of the East African Rift (Kenya and Tanzania) prospecting for the origin of man, Cousteau charting undersea life, Goodall charting chimpanzee life (Tanzania), the American Mount Everest expedition, and the flights of the stratosphere balloons, Explorer I and Explorer II.

These are the seeds of National Geographic Research, a new scientific journal devoted primarily (but not exclusively) to publishing the results of the studies that the Society funds. Ironically, the first issue (Winter 1985) fulfilled a 76 year-old resolution by the Board of the National Geographic Society to "undertake the publication of a technical geographic journal to be separate from the National Geographic Magazine". Until 1985, grant recipients summarized their findings in the Society's annual Research Reports, a tome that is the very antithesis of geography: a ledger of stiff, dry tracts devoid of maps or photographs.

Not so National Geographic Research, the handsomest, most elegant professional scientific journal known to me. Its origin from the musty Research Reports is a remarkable speciation, and it finally puts the lie to Dawson's axiom that if it's handsome, it's art; if it's science, it's dull. What a magnificent revelation to see hard science in colour and not on public television. Natural science is usually a comic duality. In the field it studies a universe of magisterial colour; in print it becomes a stark black and white. But not here National Geographic Research is a dazzling display of natural history in polychrome. The drawings, charts, maps and photographs, many of them prepared by the Society's art staff, are vivid with colour and are worth the proverbial thousand words. They impart the immediacy of an eye witness account, the excitement of science in the flesh. As a result, the few black-and-white illustrations in each issue, although superior, are a comedown. Of course, fine artwork demands, and receives, the finest paper.

If the style is a knockout, what about the substance? The knee-jerk tendency among too many academics is to succumb to a kind of elitism that afflicted the "serious" art world long ago, namely, the critical platitude that the attractive or popular cannot be serious. Again, not here. The "research" in National Geographic Research is as solid and scholarly as that in any first-rate scientific journal, if not more so; each paper must pass the muster of at least two outside referees to be considered for publication. The Board of Editors, which reads like a Who's Who of natural history, and the editor Harm J. de Blij, have reminded us of the matching valence of erudition and beauty in science and its communication.

The writing in National Geographic Research, for the most part, is unusually lucid, perhaps because the authors are aware of the journal's broad scope and audience and are willing to make the effort to make their geology, for example, understandable to an ethologist without sacrificing the subtle technical shadings of the science. The cross-disciplinary breadth of National Geographic Research is true to its geographic roots and a refreshing antidote to libraries stacked with specialized journals. The seven issues to date have included articles on vertebrate palaeontology, archaeology, ethology, urban anthropology, ethology, ecology, palynology, zoology, geology, historical geography, primatology, entomology, biogeography and botany. The connecting thread is the science of place.
Each issue of National Geographic Research has four sections: "Articles", for longer reports; "Forum", for shorter papers; "Noted Elsewhere", for capsule summaries of Society-funded research published in other journals; and "Letters to the Editor", where authors can also rebut critics. In a nice touch that is loyal to the geographic tradition, the title page of each article features a colour globe with the appropriate geographic area demarcated by a yellow rectangle, the insignia of the Society.

National Geographic Research, like its less technical but more famous cousin, National Geographic Magazine, is entirely supported by subscriptions. The latter, a veteran of 98 years, boasts an audience of over three million; the former, a rookie, reached 4,000 subscriptions at last tally (the Winter 1985 issue). That 4,000 number should grow, if only because grand science in great colour should scduce the libraries, the curious and all practitioners of natural history and classical geography.

Leonard Krishtalka is Associate Curator in the Section of Vertebrate Fossils, Carnegie Museum of Natural History, 4400 Forbes Avenue, Pittsburgh, Pennsylvania 15213, USA.

\section{Public talk about human affairs}

\section{Paula Brown Glick}

Anthropology Today. Editor Jonathan Benthall. Royal Anthropological Institute, 56 Queen Anne Street, London WIM 9LA, UK. 6/yr. UK £10 (institutional), £7 (individual); North America $\$ 14$ (institutional), $\$ 12$ (individual).

The Royal Anthropological Institute has revised its journals format more than once since 1965. Anthropology Today is an enlarged and illustrated successor to Royal Anthropological Institute News (RAIN), while the quarterly Man, is devoted to longer articles, reviews and related correspondence. An amalgam of news, announcements, reviews, short research articles and commentary, Anthropology Today is to be distinguished by "its orientation towards the world outside: that is, towards public and topical issues and towards other professions". The journal seeks to inform about the work of anthropologists, to cover all tendencies and movements, to debate issues, and to carry information of both national and international concern.

What might this new-found public for anthropology find of interest? Minorities, refugees, ethnic conflict, victimization of tribal peoples are subjects on which anthropologists often have field experience as well as concern: Survival Inter- 